\title{
Kent Hakkı ve Katılımcılık Bağlamında Kendin Yap Kentleşme: Roma Bostanı Örneği
}

\section{Do-lt-Yourself Urbanism within the Context of Right to the City and Participatory Urbanism: The Roma Garden}

\section{Gökçe Öcal, ${ }^{1}$ (D) Gülden Erkut ${ }^{2}$}

${ }^{1}$ İstanbul Teknik Üniversitesi, Fen Bilimleri Enstitüsü, Şehir ve Bölge Planlaması Bölümü, İstanbul

${ }^{2}$ İstanbul Teknik Üniversitesi, Mimarlık Fakültesi, Şehir ve Bölge Planlaması Bölümü, İstanbul

\section{ÖZ}

Bu makale, “Kendin Yap Kentleşme” bağlamı içerisinden İstanbul'da halen sürdürülmekte olan bostanlardan olan Cihangir Roma Bostanı'na odaklanmaktadır. İstanbul'da kent içi tarım alanları olan bostanların geçmişi yüzyıllar öncesine dayanmakla birlikte son bir kaç yıl Türkiye'nin İstanbul başta olmak üzere birçok kentinde "kendin yap" bostanların kurulmasına sahne olmuştur. Bu bostanlar, öz-örgütlenme yoluyla bir araya gelmiş olan katılımcıların kendilerine ait olmayan araziler üzerinde, "izinsiz" olarak hayata geçirdikleri ve kendi imkanlarıyla kolektif olarak sürdürdükleri, kullanım değerinin öne çıtı̆̆ı ve gıda üretiminin sembolik kaldığı mekânlardır. Bu makale dayanışma, ortaklaşma ve karşılıklı öğrenme mekânı olan Cihangir Roma Bostanı'nı bir doğrudan katılımcı bir kamusal mekân talebi olarak Türkiye'nin ve özelde İstanbul'un kamusal ve yeşil mekânlarının artarak yok edildiği neoliberal kent politikalarına karşı "kent hakkı” çerçevesinden tartışmayı amaçlamaktadır.

Anahtar sözcükler: Kendin yap kentleşme; kent bostanları; kent hakkı; katilimcilik.

\begin{abstract}
The present study focuses on one of the last remaining urban gardens, the Roma Garden in Istanbul, Turkey, in the context of "DIY urbanism.” Urban agriculture has a very long history in Istanbul where traditional urban market gardens called "bostans" provided the city with food for centuries. While the last remaining historical gardens are now under threat due to municipal policies favoring urban development, Istanbul has witnessed the formation of "DIY" urban gardens in 2013. These gardens, initiated on public land and maintained by a small group of gardeners, are open to the public without any legal relation to the local state. In contrast to the last remaining historical "bostans," these gardens, organized around the use value, are managed solely by gardeners, and the harvest is not meant to be nourishment, rather it has a symbolic value. The empirical research that the present study is based on shows that the destruction of urban public space in general and public green space in particular over the last decade in Istanbul paved the way to DIY public gardens as spaces of solidarity, collectivity, and shared knowledge, as well as spaces where ecological concerns can be raised and made visible. The present study also explores the ways in which these urban gardens contribute to envisage a new kind of urban opposition centered around the demand for public space against the neoliberal urban policies.
\end{abstract}

Keywords: Do-it-yourself urbanism; urban gardens; right to the city; participatory urbanism.
Geliş tarihi: 15.05.2018 Kabul tarihi: 16.04.2019

Online yayımlanma tarihi: |4.06.2019

İletişim: Gökçe Öcal.

e-posta: gokceogokce@gmail.com 


\section{Giriş}

Son yıllarda dünyada olduğu gibi Türkiye' nin çeşitli kentlerinde de literatürde "Do It Yourself Urbanism" - "kendin yap kentleşme" olarak adlandırılan kentsel pratikler ilgi çekici olmaya başlamıştır. Çoğunlukla birbirinden farklı ve bağımsız çeşitli kişi ve grupların kentsel mekânlara izinsiz, enformel müdahalelerini içeren bu eylemler ve pratikler, kentsel mekânları kimi zaman geçici ve anlık olarak dönüştürmeyi hedeflemekte, kimi zaman uzun erimli bir dönüşümün yolunu kentsel mekânı belirlenmiş, tanımlanmış, planlanmış işlevinin dışında farklı kullanım biçimlerine açarak ve farklı anlamlandırmaları mümkün kılarak gerçekleştirmektedir. Tabandan gevşek bir biçimde organize olan bu "kendin yap" kentleşme pratikleri taktikler ve yaratıcı eylemler yoluyla aktivizm, kentsel tasarım ve planlama arasındaki ayrımları silikleştirmekte, kent mekânı üzerinde hak iddia etmekte ve kenti farklı kullanımlar yoluyla dönüştürmeyi hedeflemektedir. Bu bağlamda, sokak sanatından, grafitiye, işgal evlerinden, alternatif toplu ulaşım gruplarına, kent bahçeciliğinden, reklam tabelalarını bir gecede değiştirmekten yaratıcı kent mobilyaları inşa etmeye mekânlara oyuncu bir biçimde geçici müdahalelerde bulunan topluluklara kadar geniş bir yelpazede değerlendirilebilecek olan bu pratikler yeni bir kentsel ve toplumsal muhalefetin habercisi olabilir. Kentlerin anti-demokratik yollarla, yukarıdan-aşağı kararlar ve süreçlerle planlandığı ve büyük ölçüde metalaştığı günümüzde böyle pratiklerin öncelikle kentsel katılımcılık, kent hakkı ve kentsel planlama ve tasarım ile kurabileceği ilişkiler üzerine düşünmek önem kazanmaktadır. Böyle pratikler bir yandan daha adil ve kapsayıcı bir kentsel politikaya ve gerçek anlamda katılımcı bir kentselliğe doğru açılımlar ihtiva ederken, bir yandan da anlamlı ve bütünlüklü bir kentsel muhalefet üretmekten yoksun kalma riskini beraberinde taşımaktadır.

İstanbul'da kentsel tarım, yani geleneksel "bostan”larda şehrin tüketimi için gıda üretimi, Bizans'a kadar uzanan bir geçmişe sahiptir (Kaldjian, 2004). Bostanlar; yerel pazara gıda sağlamanın ve çiftçiler için geçim kaynağı olmanın yanı sıra bugün tarihsel ve arkeolojik alanlar olmaları sebebiyle de önem taşımaktadırlar. Günümüze dek ayakta kalabilmiş bu bostanların varlığı kentsel kalkınmayı yeğleyen politikalar nedeniyle son dönemlerde tehdit altına girmiştir (Durusoy \& Cihanger, 2016). "Kendin yap kentleşme" olgusu içerisinden değerlendirilebilecek olan kent bahçeleri İstanbul'da görece yeni ortaya çıkmış bir olgudur ve bu bahçelerin doğası ve kentsel önemine iliş̧in yeterli çalışma yapılmamışır (bir istisna için bkz. Ateş, 2015).' Bu makale İstanbul'da Cihangir Mahallesi'nde bulunan Roma Bostanı'na "kendin yap kentleşme" bağlamında odaklanmaktadır. Küçük bir bahçeci grubunun bakımını üstlendiği ve kamu arazisi üzerinde oluşturulan bostan, yerel yönetimle herhangi bir yasal bağı olmaksızın kamuya açıktır. Ayakta kalan son tarihi bostanların aksine, kullanım değeri ile örgütlenmiş olan bu bostanlar yalnızca bahçeciler tarafından yürütülmekte ve hasat beklentisinden çok simgesel değeri için yapılmaktadır. Bu makalenin dayandığı ampirik araştırma, İstanbul'da genelde kentsel kamusal alanın, özelde ise kamusal yeşil alanların son yıllardaki tahribinin, kolektif dayanışma ve bilgi paylaşım alanları olduğu kadar ekolojik kaygıların dillendirildiği ve görünür kılındığı alanlar olan kendin yap bostanları ortaya çıkardığını göstermektedir. Bu makale, söz konusu kentsel bahçelerin, neoliberal kentsel politikalara karşı kamusal alan talep eden doğrudan katılımcı bir kentsel muhalefetin tahayyül edilmesine nasıl katkıda bulunduğunu araştırmaktadır. Beyoğlu Cihangir'de bulunan Roma Bostanı'na odaklanan makalenin amaçları, bostancıların bostana ve bostancılığa atfettiği anlamları ve motivasyonları belgelemek, bostanın oluşturulması ve bakımının neoliberal kentsel yönetimlere karşı doğrudan katılımcı bir kamusal alan talebi olduğunu göstermek ve bu talebi kent hakkı kavramıyla çözümlemektir.

Bu makalede önce "kendin yap kentleşme" kavramı tartışılacak, kent bahçelerinin "kendin yap kentleşme" içerisinden nasıl anlaşılabileceğine değinilecek ve "kendin yap kentleşme" ve planlama arasındaki ilişki sorunsallaştırılacaktır. Makale daha sonra Roma Bostanı'nın kuruluşu ve dönüşümü üzerinden bostanın "kent hakkı" ve katılımcılık bağlamında bir değerlendirmesini yapacaktır.

\section{"Kendin Yap Kentleşme"}

"Kendin yap kentleşme" kentsel tasarımın alışıldık ve kurumsallaşmış biçimlerinden ayrı bir şekilde, izinsiz müdahaleler yoluyla kamusal alanı geçici veya kalıcı bir süre için, yaratıcı bir biçimde sahiplenmeyi ve dönüştürmeyi amaçlayan küçük ölçekli, tabandan eylem ve pratiklerdir. Literatürde "gerilla kentleşme", "asi kentleşme", "taktiksel kentleşme", "pop-up kentleşme" gibi farklı kavramsallaştırmalar da mevcuttur. Doğrudan kentsel aktörlerin kendi kaynaklarıyla hayata geçirdikleri tabandan ve kullanım odaklı pratiklere vurgu yaptığı için bu makale "kendin yap" tanımını benimsemiştir. Ancak bu pratiklerin ölçek, süre, motivasyon ve daha geniş çaplı etkilerindeki farklılıklar genel bir tanım ve çerçevenin çizilmesini zorlaştırmaktadır (Iveson, 2013). Bir yelpazenin farklı noktalarında konumlanabilen bu kadar çeşitli aktivitenin bir şemsiye kavram altında toplanmasını sağlayan ortaklık mekânsal pratiklerin içeriğinden çok kentsel mekân, politika ve kente dair içerdikleri potansiyel önermeler ve olasılıklarla ilişkili görünmektedir. Zardini, formel kentleşme içinde bireysel veya kolektif eylemler şeklinde ortaya çıkan bu pratiklerin "alternatif hayat tarzları önerdiğini, gündelik yaşamlarımızı yeniden icat ettiğ̈ini ve kent mekânını yeni kullanımlarla yeniden işgal ettiğini” (Zardini, 2008, s. 16) söyler. Hou'ya göre bu kentsel deneylerin or-

Bu makalenin dayandığı araştırmanın sahasını oluşturan Cihangir Roma Bostanı dışında 20 I I yılında Boğaziçi Üniversitesi Yerleşkesi içerisinde kurulmuş ve hala aktif olan Tarla Taban, 2013 yılında kurulan ancak 2018 itibariyle aktif olmayan Kadıköy Moda Bostanı ve Üsküdar İmrahor Bostanı “kendin yap” hareketi bağlamında değerlendirilebilecek bostanlardır. 
tak yanı "kent içinde kentleri" keşfetmek, ortaya çıkarmak ve onları "yeni işlevler ve anlamlarla donatmaktır" (Hou, 20I0, s. 2). Zeiger ise bu pratiklerin içerisinde ekonomik ve politik engellere veya disipliner veya kurumsal atalete rağmen değişimin mümkün olduğuna ilişkin bir inanç (Zeiger, 20II) olduğunu iddia eder. Douglas'a göre "kendin yap kentleşme” pratikleri, aktörlerin motivasyonları, eylemlerinin çeşitliliği ve öngörülen veya öngörülmeyen etki ve sonuçları ne olursa olsun "bireylerin veya enformel grupların belirli kentsel mekânların belirlenmiş, düzenlenmiş kullanımlara izinsiz şekilde doğrudan müdahaleleriyle meydan okumalarıdır" (Douglas, 20।4, s. 8). Dolayısıyla böyle pratikleri kente müdahalede bulunan diğer tür eylemlilik biçimlerinden ayıran, var olan kullanımları sorgulayarak yeni kullanım biçimleri tarif etmeleri ve izinsiz olarak hayata geçirilmeleridir (Douglas, 20I4). Finn, "kendin yap kentleşme" yaklaşımlarının en belirgin özelliklerinden birini bu tip yaklaşımların motivasyonunun tek tek bireylerin veya küçük gönüllü grupların herhangi bir yerel yönetim veya özel girişim desteği aramaksızın kentsel mekânda önemli gördükleri karşılanmamış bir ihtiyaca çözüm bulmak olduğunu belirtirken, böyle pratiklerin işlevsel niteliğine ve tüm kentin yararına olması gerektiğine vurgu yapar. (Finn, 20I4, s. 383).

Fabian ve Samson'a göre "kendin yap kentleşme” pratiklerinin aktörlerin kendilerini kentsel mekâna kazımak, mekâna bağlanmak, görünür olmak ve başkalarıyla ilişkilenmek gibi özelliklerinin yanında kamusal alanla ilgili yeni deneyimler üretmek ve kent mekânına ilişkin algıları dönüştürmek gibi anlamlarının yanında kamusal alanın kim tarafından nasıl kullanılabileceğine ilişkin çok temel bir sorunsalı görünür kıldıklarını, mekânın kamusal ve toplumsal boyutları üzerine farklılıkların birlikte yeni anlamlar müzakere edebileceği bir alan açtıklarını belirtirler (Fabian \& Samson, 2016, s. I70). Dolayısıyla "kendin yap kentleşme” pratikleri, içinden geçtiğimiz dönemde kamusal alanın inşası, "açıklığı” ve bunları şekillendiren iktidar biçimlerinden ayrı olarak düşünülemez.

“Kendin yap” kentleşme, kentsel mekânı güzelleştirmekten kentsel estetiğe (Talen, 2015), kentsel mekânda hissedilen bir eksikliği gidermekten, kentte işlevselliğe, kentsel mekânda iktidar ilişkilerinin açık edilmesi, ters yüz edilmesi, bozguna uğratılması, yeni anlamlar ve kullanımlar açması bağlamında da doğrudan mekânın alternatif biçimlerde üretimi çerçevesinde dikkate değer görülmüştür. Yalnızca pratiklerin ürettiği sonuçlar değil, ondan daha da önemlisi bu pratikler üretilirken işe koşulan alternatif eyleme, birlikte üretme, karar alma ve ilişkilenme biçimleri hem kentsel katılımcılık (Finn, 20I4a), hem de kent siyaseti (Spataro, 2016) alanlarında verimli bir tartışmayı beraberinde getirmiştir.

Türkiye'de ise "kendin yap kentleşme" kavramı ile ilişki içerisinde yapılmış az sayıda araştırma vardır (Kaya \& Görgün, 2017). Örneğin Kaya ve Görgün, Türkiye'den “kendin yap kentleşme" örneklerini inceleyen araştırmalarında, "kendin yap kentleşme" içerisinden değerlendirilebilecek örneklerin aktörlerin amaçları bağlamında kentsel estetik, ihtiyaç, ticari fayda ve tepki olarak ortaya çıktığını, aktörlerin ise mahallelilerden, STK'lara, belediye/kamu kurumlarından, özel işletmeler ve aktivist gruplara kadar çeşitlilik gösterdiğini tespit etmişlerdir. Bu araştırmaya göre Türkiye'de "kendin yap kentleşme" alanında ihtiyacın karşılanmasına yönelik uygulamalar ön sıradayken, aktör olarak mahalleliler ön plana çıkmaktadır (Kaya \& Görgün, 2017: 72).

\section{“Kendin Yap” Kent Bahçeleri}

Kent bahçeciliği akademik literatürde çok çeşitli şekillerde tartışılmaktadır. Dünyanın değişik yerlerindeki kent bahçeleri ölçek, işlev, karakteristik ve içinde bulundukları bağlam açısından farklılaşırlar. Topluluk bahçeleri, gönüllüler tarafından idame ettirilen (Rosol, 2010: 552), yerel yönetim/devlet, kamusal ve özel girişimler ile ya ilişkisi olmayan, ya da farklı seviyelerde ilişkileri olan alanlardır. Bu perspektife göre, kolektivite ve kamusallık bir kentsel bahçenin belirleyici özellikleridir. Bazı çalışmalar kent bahçelerini gıda siyaseti açısından ve kentsel tarım bağlamında çözümlemişlerdir (Ferris, Norman \& Sempik, 200I; Baker, 2004). Literatürde kent bahçeleri genel olarak, etnik ve/veya sınıfsal topluluğa sağladığı ekonomik ve sosyal faydaları ile sağlığa yararları açısından (Mares \& Peña, 20।0) ve bunun yanı sıra topluluk oluşturmadaki yararları açısından (Saldivar Tanaka \& Krasny, 2004) ele alınmaktadır. Diğer yandan kent bahçeleri, kolektif çevre eğitimi ve toplumsal güçlenme alanları olarak (Bendt, Barthel \& Colding, 20I3) ve kentsel sürdürülebilirliğe katkıları yönünden de (Holland, 2007) incelenmiştir. Bazı çalışmalar kent bahçelerini, var olan neoliberal kentsel ve toplumsal politikalara karşı çıkan mücadele alanları olarak yorumlamıştır (Schmelzkopf, 2002; Crossan, Cumbers, McMaster \& Shaw, 20I6). Öncelikli olarak bahçelerin sunduğu vaat ve potansiyellere odaklanan bu çalışmaların yanı sıra, kent bahçelerinin neoliberal politikaları yeniden üretip dayatabileceği (Pudup, 2008; Rosol, 20I2) veya soylulaştırmayı güçlendirebileceği (Marche, 20I5) de tartışılmıştır.

Bu geniş tartışma içerisinde "gerilla bahçecilik" olarak tanımlanan bir mekânsal müdahale türü de son zamanlarda literatürde ilgi görmeye başlamıştır. Gerilla bahçecilik faaliyetleri genellikle, kentsel bahçeciliğin daha organize veya kurumsallaşmış biçimlerinden farklı olarak, aktörler tarafından her türlü toprak parçasına yapılan izinsiz müdahaleler olarak görülmektedir (Reynolds, 2008; Hardman, 20II). Birçok çalışma gerilla bahçeciliği "direniş” merceğinden ve var olan toplumsal-mekânsal düzenlemeleri ters yüz etme, dönüştürme ve mülkiyet ilişkileri, artan metalaşma ve kamusal alanın kontrolü gibi düzenlemelere karşı çıkma potansiyeli açısından (Reynolds, 2008) yorumlamış, böylelikle bu pratikleri "eleştirel kentsel bahçecilik" denilebilecek siyasi pratikler olarak de- 
ğerlendirmiştir (Certomà, 20II). Gerilla bahçeciliği direniş̧̧i bir siyasi eylem olarak gören yaygın yoruma rağmen, bazı çalışmalar gerilla bahçecilik pratiklerinin mahalleyle, yerel yetkililer ve planlama aktörleri ile daha karmaşık bir ilişkisi olabileceğini göstermektedir (Thompson, 20I5). Daha geniş bağlama bağlı olarak bu pratikler ana akım planlama ve tasarım eğilimlerini yansıtabilir ya da bu eğilimlere uyum gösterebilir (Tornaghi, 2012, Adams \& Hardman, 20I4), hatta bir nevi meşruluk kazanabilirler (Hardman, 20II).

\section{Taktiksel Kentleşme: Planlamada Katılımclıkta Yeni Bir Dönem mi?}

"Kendin yap kentleşme" olarak da adlandırılan pratikler kimi yazarlarca "taktiksel kentleşme" (Lydon \& Garcia, 2015) veya "taktiksel planlama" adıyla yeni ve farklı bir planlama anlayışı olarak tartışımaya başlanmıştır. Lydon \& Garcia, taktiksel kentliliği sıradan vatandaşlardan, girişimlere, hükümetlerden, uzmanlara çok çeşitli aktörlerin hayata geçirebileceği şeffaf, kısa erimli, düşük maliyetli ve ölçekli, uzun erimli konvansiyonel kent planlama yöntemlerine karşıt ortaya çıkarılabilen toplumsal ilişkilerin yaratııı potansiyelinden de güç alan bir yaklaşım olarak tanımlamaktadırlar (Lydon \& Garcia, 2015: 2-3). Bu noktada, literatürde "kendin yap kentleşme" olarak tarif edilen pratiklerle "taktiksel kentliligin" aynı şey olmadığııın altı çizilmelidir. "Kendin yap kentleşme" yerel yönetimler, uzman kadrolar, hükümetler veya girişimler gibi kurum ve aktörlerden bağımsız ve izinsiz harekete geçirilen pratiklere işaret ederken, "taktiksel kentleşme" kavramında her türlü formel veya enformel kurum veya girişimin de bu pratiklerin uygulayıcısı olabileceği savı vardır. Yazarlara göre "kendin yap" pratikler "taktiksel kentleşmenin" temel eksenini oluşturmaktadır. Yine aynı yazarlar "taktiksel kentleşmenin" uygulamada en yaygın üç örneğinin görüldüğünden bahsederler; vatandaşlar tarafından görsel olarak değişimin mümkün olduğunun gözler önüne serildiği, genellikle devlet bürokrasisi veya alışımış proje süreçlerini baypas eden müdahaleler; yerel yönetimler, yatırımcılar ve kar amacı gütmeyen kuruluşların planlama ve uygulama adımlarında katılımcılığı genişletmek ve derinleştirmek için kullandıkları araçlar; ve kentler veya yatırımcılar tarafından uzun erimli yatırım gerektiren bir projeyi hayata geçirmeden önce deneme olarak uygulananlar (Lydon \& Garcia, 20I5:12). Görülmektedir ki, bu yazarlara göre "taktiksel kentleşme" verili kentsel politikalara, kararlara veya yapılı çevrenin belirli bir şekilde düzenlenişine bir eleştiri veya muhalefet olarak ortaya çıkmakla beraber bizzat o planları geliştirenler, uygulayanlar ve hatta ticari bir kaygıyla yapanlar tarafindan da bir strateji olarak uygulanabilir. Taktiksel kentliliğin özellikle Batı coğrafyasında yaygınlaşması ve böyle pratiklere duyulan ilginin nedeni, kimi yazarlarca siyasi, ekonomik ve çevresel belirsizliklerin artması, sanayisizleşme nedeniyle kentlerde atıl alanların ortaya çıkması ve artan oranda hareketli olan bir işgücünün daha esnek mekân ve kullanımlara ihtiyaç duyması olarak açık- lanmıştır (Bishop \& Williams, 20I2). Bergdoll'a göre "taktiksel kentleşme" gerek küresel ölçekte yükselişte olan neoliberal ekonomi politikaları ve bütüncül kapsayıcı planlamanın çökmesine bir cevap olarak ortaya çıkan büyük oranda pragmatik ve esnek pratiklerdir (Bergdoll, 20I5: 12). Gadanho "taktiksel kentleşmeyi" formel kentin akılcı üretimin karşısında ortaya çıkan "çağdaş kentlerin çelişkili koşullarının yaratııı ve becerikli temellügüu” (Gadanho, 2015: 19) olarak tanımlarken Sassen "taktiksel kentleşmenin" güçsüzlerin kendilerini görünür ve var edebilecekleri bir güç, sessizleştirilmiş ve dışlanmışların seslerini duyurabilecekleri bir mecra olabileceğinden bahsetmektedir (Sassen, 2015: 4I-47). Bu anlamda yalnızca parçacıl bir tasarım pratiği/ürünü olmanın ötesinde böyle pratikler politik özneleşmenin de yolunu açmaya muktedir görülmektedir. Her ne kadar çok çeşitli pratik, oluşum, tasarım ve ilişkilenme biçimlerine işaret etseler de literatürde özellikle öne çıkan taktiksel kentliliğin doğrudan katılımcllı̆a yaptığı vurgudur ve aşağıda sıralanan özellikler tabandan katılımcılığı taktiksel kentliliği tanımlamanın temel odağı haline getirmektedir.

Burada sorulması gereken taktiksel kentleşme pratiklerinin konvansiyonel planlama karşıtı, kısa vadeli, geçici, akıcı ve spontane olmaları itibariyle konvansiyonel ve hatta güncel katılımcı planlama paradigmalarıyla karşıtlık oluşturmaları ve bu özellikleriyle neoliberal kent politikalarına gerçek ve somut bir alternatif olup olmayacakları noktasıdır. Literatürde taktiksel kentleşme daha ziyade neoliberal kent politikaları karşısında muhalif, meydan okuyucu ve kimi zaman dönüştürücü bir güç olarak görülmekle birlikte, bazı çalışmalar da böyle pratikler ile hem neoliberal kent politikaları, hem de kentsel planlama ve tasarım arasında daha karmaşık ve çetrefilli bir ilişki olduğu sonucuna varmıştır. Brenner (20I5), kente taktiksel müdahale biçimleri ve hegemonik neoliberal kent politikaları arasında olası en az beş ilişki biçimi tespit etmiştir. Brenner'a göre bu biçimlerden ilki olan güçlendirme neoliberal yönetişimin sınırları dahilinde cereyan ettiği ve onun düzenleyici çerçevesi ve mantığına temelden bir müdahale olmadığı için, ikincisi olan sağlamlaştırma, taktiksel kentliliğin kendisi neoliberal bir programı benimsediği veya kamu kurumlarının kentsel servis sağlamadaki rolünü ve önemini azalttığı için; üçüncü biçim olan tarafsızlık da taktiksel kentliliğin kendisinin çoğu zaman neoliberal rejim için işlevi olmayan ara alanlarda gerçekleştiği ve dolayısıyla egemen kent politikalarını rahatsız etmeden var olmasını sağladığı için yaratıcı ve dönüştürücü bir gücü yoktur. Brenner’a göre bu ilişki biçimlerinden son ikisi; altüst etme ve olumsallık olarak tarif ettiği biçimler, kente egemen neoliberal politikalara bir meydan okuma olasılığına sahip olabilir. Altüst etme, taktiksel kentliliğin büyüme odakıı, pazar yönelimli yönetişim mantığını durdurarak, katılımcı, kullanım değeri ve kullanıcı odaklı tabandan bir demokrasi ve sosyal adalet sağlayabilir. Olumsallık özelliği nedeniyle ise taktiksel kentleşme deneysel anlamlar yaratabildiği için neoliberal politikaların ters yüz edilmesine olanak verebilir. Dolayısıyla 
taktiksel kentleşme içerisinden değerlendirilebilecek pratikler içinde bulundukları bağlamla, aktörlerle, aktörlerin çevreyle kurdukları ilişkilerle ve niyet edilen ve niyet edilmemiş sonuçlarıyla birlikte düşünüldüklerinde kimi zaman bir imkan, kimi zaman da egemen ideolojiye eklemlenen ve onu destekleyen pratikler olarak düşünülebilir. Buradan hareketle, Cihangir Roma Bostanı'nın İstanbul'da kentsel katılımcılık bağlamında nasıl ifadesini bulduğu makalenin devamında kent hakkı çerçevesinden tartışılacaktır.

\section{Cihangir Roma Bostanı}

Roma Bostanı 2013 yılının Temmuz ayında Beyoğlu ilçesindeki Cihangir semtinde yaklaşık 15 kişilik bir grup tarafından "kendin yap" yöntemiyle kurulmuştur. ${ }^{2}$ Mayıs 2018 itibariyle Roma Bostanı hala aktif bir bostandır. Roma Bostanı yaklaşık I dönümlük bir kamu arazisi üzerinde, yıllardır atıl duran ve Beyoğlu'nun Cihangir mahallesinde "merdivenler" olarak tarif edilen Boğaz manzaralı merdivenlerin sol tarafında konumlanmıştır. Bostanın kurulma fikri Cihangir Park Forumu 'nda ortaya çıkmış, bu fikri benimseyenlerce hızla bir "bostan grubu" oluşturulmuş ve akabinde bostanın kurulması için Cihangir mahallesinde yer seçimi çalışmalarına başlanmıştır.

$\mathrm{Bu}$ makalenin dayandığı araştırma tasarımı oluşturulurken İstanbul özelinde "kendin yap kentleşme" bağlamında tanımlanabilecek oluşumlar içerisinden "kendin yap" kent bostanlarına odaklanılmıştır. Örneklem seçimindeki iki kriter ilgili "kendin yap" literatürüne dayanarak bostanların tabandan sivil inisiyatifle "kendin yap" olarak kurulmuş olması ve yerel yönetimle herhangi bir izin/onay ilişkisi içerisinde olmamasıdır. Amaçlı örnekleme (purposive sampling) yöntemi yoluyla vaka (örnek olay) olarak seçilmiş ve katılımcılar, katılımcı gözlem ve yarı-yapılandırılmış açık uçlu sorular ile derinlemesine görüşme tekniği ile incelenmiştir. Bostanların kuruluşu ve dönüşümleri bostancıların aktif katkıları, öznel algı ve tutumlarıyla şekillendiğinden onların anlatısı ve anlamlandırmaları araştırma için temel bir öneme sahip olmuştur. Bu makalenin dayandığı saha araştırması kapsamında kuruluşundan bu yana Roma Bostanı'nda aktif olarak çalışmış/çalışan 15 kişi ile derinlemesine mülakat yöntemiyle görüşülmüştür. Görüşülen bostancıların 10'u kadın, 5’i erkektir. Bostancıların yaşları 30 ile 55 yaş arasında değişmektedir. Bostancıların biri lise, diğerleri üniversite mezunudur. Meslek bağlamında heterojen bir grup olan bostancılardan kamu görevlisi olarak çalışan yoktur. Farklı özel sektör alanlarında çalışanlar olduğu gibi, düzenli gelire sahip olmayan yaratıcı sektörlerde çalışanlar da vardır. Görüşme yapıldığı dönemde bostancılardan ikisi işsizdir. Yine görüşme yapıldığı sırada bostancıların dokuzu Cihangir'de yaşamaktadır. Bostancıların hiçbiri siyasi bir parti, örgüt veya derneğe üye değildir.
Roma Bostanı'nın kurulma hikayesinde kurucuların kendi anlatımlarına göre Cihangir Forumu'ndaki tartışmalar önemli bir rol oynamıştır. Roma Bostanı kurucuları kentsel alanlara yapılan ve anti-demokratik olarak algıladıkları uygulamalara bir tepki bağlamında mahallelerinde bir bostan kurmak istemişlerdir. Keza, Roma bostanının kurulması için seçilen alanın Beyoğlu Belediyesi tarafından imara açılmak istendiğine dair duyumlar bu alanın kurucular tarafından seçilmesinde etkili olmuştur. Görüşme yapılan pek çok bostancı ${ }^{3}$ bostan arazisinin mülkiyet durumunu bostan yapılırken bilmediğini, arazisinin özel veya kamu arazisi olmasıyla ilgilenmediğini, her şartta o arazinin yıllardır atıl durduğunu ve arazinin herkese ait olduğunu vurgulamak için tam da araziyi işgal ederek bostana dönüştürmenin önemli olduğunun altını çizmiştir. Arazi seçilirken ve bostan çalışmaları başladığında hiçbir kamu otoritesi veya yetkili ile temasa geçilmemiş, resmi bir izin veya onay alınmamıştır. Bu ilişkisizlik bağlamında Roma Bostanı'nın “izinsiz” kurulan bir “kendin yap” mekânı olduğu söylenebilir. Bu ilişkisizlik bostancılar tarafından özellikle tercih edilmiş, kendi inisiyatifleri ve kendi mahallerinde ortaklaşa kurdukları bir mekân yaratma çabasının bir ifadesi olmuştur. Cihangir Mahallesi yeşil alanın çok az olduğu bir mahalledir. Kapalı bir otoparkın üstüne inşa edilmiş ve büyük çoğunluğu beton zeminden oluşan Cihangir Parkı ve Roma Bostanı'nın hemen aşağısında bulunan ancak genellikle cam kırıkları ve çöp ile kaplı olan Roma Parkı'ndan başka bir yeşil alana sahip değildir. Bostanın kurulmasında kurucuların kendi istek ve ihtiyaçları doğrultusunda şekil verebilecekleri bir yeşil alan yaratma isteği de etkili olmuştur.

Bostan arazisi Cihangir Forumu'nda alınan karar ve bostan grubu oluşturulmasını takiben kısa sürede belirlenmiş, arazinin belirlenmesinde arazinin hem yıllardır atıl olması, hem imara açılma planlarının varlığının bilinmesi, hem de arazinin toprak olması rol oynamıştır. Dik ve eğilimli arazi, yıllardır atıl kalmasının bir sonucu olarak neredeyse çöplük gibidir. Bostancılar kendi imkanlarıyla araziyi bir ay süren çalışmalar sonucu temizlemişler, toprağı ekip biçilebilir hale getirmişler ve yine kendi imkanlarıyla toprağa sebze fideleri dikmişlerdir. Roma Bostanı'nın sürdürülebilir olması için en temel ihtiyaç sudur ve bostancılar suyu bostanın hemen arkasında bulunan apartmandan apartman sakinleri ve yöneticisiyle konuşarak bir ücret karşılığı temin etmişler, apartmandan hortum çekerek sulama sorununu çözmeye çalışmışlardır. Bostancıların hemen hemen hiçbiri daha önceden tarımla uğraşmamış, ekip biçmeyi bilmeyen kişilerdir. Bostanda birbirlerinden öğrendikleri kadar bostanın etrafından gelip geçenlerden de öğrendiklerini ifade etmişlerdir. Bu anlamda bostan yeni insanlarla tanışma ve ilişkilenme fırsatı sunan bir mekân olarak da karşımıza çıkmaktadır. Roma Bostancıları bostanı açık bir kamusal mekân olarak tarif edip kurmaya çalışmışlardır. Bütün bostancılar bostanın herkesin katılımına, kullanımına ve üretimine açık bir yer ol-

\footnotetext{
2 Bostanın kurucuları eylemlerini "kendin yap" olarak adlandırmamaktadırlar ancak bostanın kuruluş şekli ve dayandığı temel pratikler bu çerçevede değerlendirilmelerin olanaklı kılmaktadır.

3 Bu makale özelinde bostan katılımcıları makalenin yazarları tarafından "bostancı" olarak adlandırılmıştır.
} 


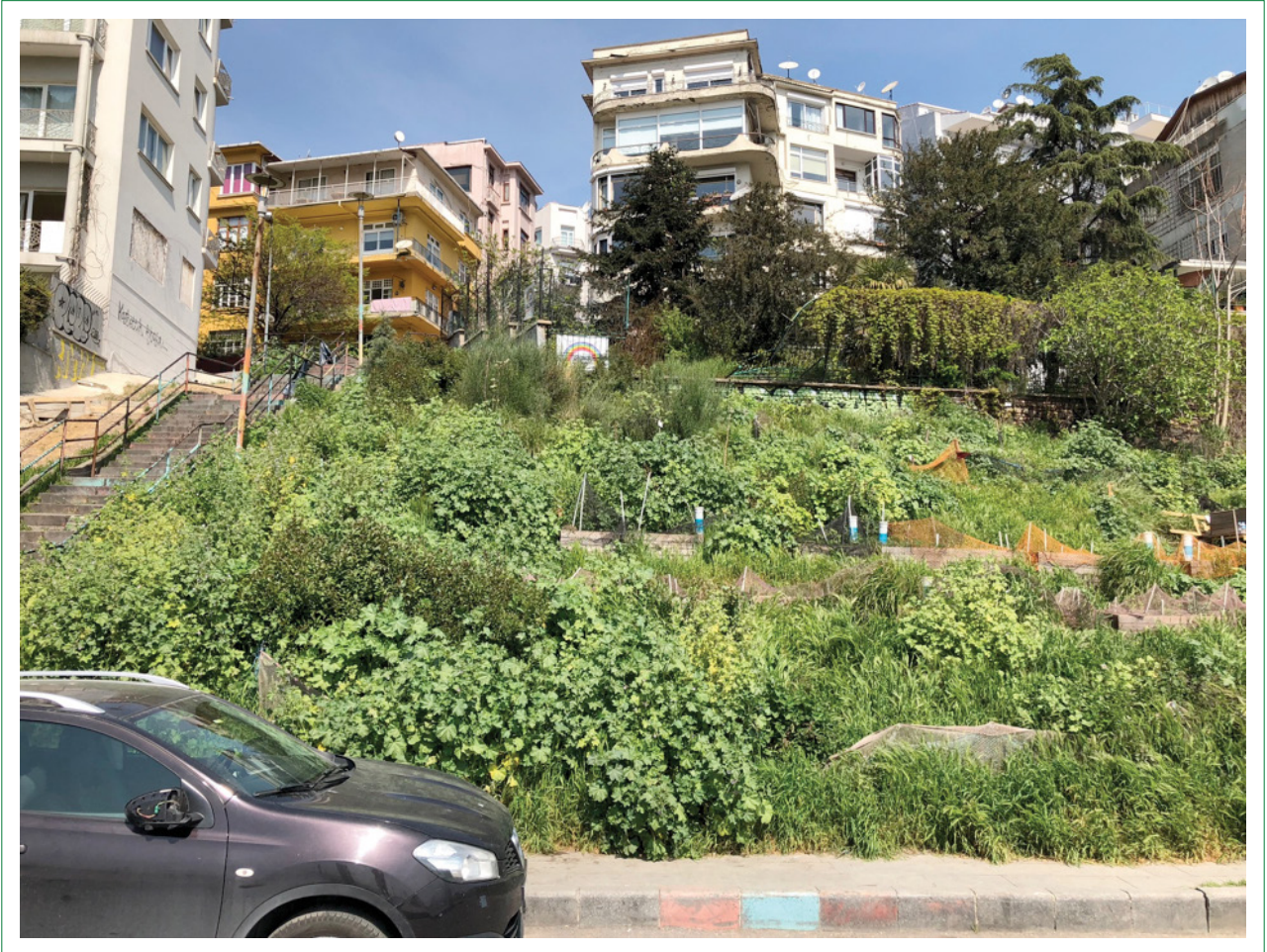

Şekil I. Roma Bostanı, Cihangir. Nisan 2018.

duğunu vurgulamışlardır. Bostandan alınan hasat da herkese ait olarak düşünülmüştür. Ne var ki bostandan ürün alınmakla beraber alınan ürün sembolik olmanın ötesine pek geçememiştir; bostancılar bostanı geçimlik bir ekonomi yaratmasından ziyade birlikte sosyalleşerek, öğrenerek, paylaşabilecekleri bir alan olarak görmüşlerdir. Yine de bostancılar, hasatlarını paylaşmışlar ve çevrelerine de sunmaya çalışmışlardır.

Bostancıların pek çoğu bostandan önce birbirini tanımazken, bostanı kurma süreciyle birlikte yakın arkadaş olmuştur. Aktif bostancılar haftanın her günü yoğun emek isteyen bostanda saatlerce çalıştıklarını belirtmişlerdir. Ancak bostan sadece ekip biçtikleri bir yer değil, onun ötesinde birlikte var olabildikleri, zaman geçirdikleri, sosyalleştikleri ve paylaştıkları bir yerdir. Kimi zaman sadece çalışmak için değil, sosyalleşmek için, dinlenmek için, gün batımını seyretmek için, sohbet etmek için bostana gittiklerini söylemişlerdir. Görüşme yapılan pek çok bostancı, hasat almaktan, hasadın niteliği ve niceliğinden çok bu ilişkisellik ve beraberlik üzerinde durmuştur. Toprakla uğraşmak ve hasat almak, bostanın ve emeğin somut bir çıktısı olarak görüldüğünden önemsenmekle birlikte, kolektif üretim, paylaşım ve birlikteliğin kendisi temel motivasyon olarak görülmektedir. Roma Bostancıları kentin farklı yerlerinden kurulan diğer bostanlarla da ilişkilenmiş, fikir ve fide alışverişi yapmıştır. Mahallede görünür olmak önemsenmekle birlikte mahalleye bostanı tanıtmak için özel bir çaba harcanmamıştır. Bostancılar, bir yıla yakın bir süre bostanla aktif olarak ilgilenmişler ancak bostanı daha fazla sürdürememişlerdir.
Roma Bostanı 2015 yılında bu kez farklı kullanıcılarla yeniden sahiplenilerek bir kez daha canlanmıştır. Roma Bostanı'nın bu ikinci doğumu bostanın ilk yılının aksine çok daha profesyonel ve uzun erimli amaç ve hedeflere yöneliktir. Bostan 2015 yılında kendini aktivist olarak tanımlayan, 35 yıllık Cihangirli, farklı kent savunma oluşumlarıyla da ilişki içerisinde olan bir mahalleli tarafından permakültür eğitimi almış profesyonel bir peyzaj mimarının da yardımıyla tamamen yeniden tasarlanmıştır. Arazideki toprak yenilenmiş, fideler için ahşap setler hazırlanmış, damla sulama sistemi kurulmuş ve Roma Bostanı sosyal medya hesabından yapılan açık çağrıya katılan yüze yakın kişinin de yardımıyla çok kısa sürede yeniden hayat bulmuştur. Çağrı çeşitli gazetelerde de yayınlanmıştır. Yaklaşık I dönümlük bir arazide görüşmecilerin deyimiyle hedef “ bilimsel permakültür prensiplerine göre tasarlanmış bir sürdürülebilir gıda ormanı yaratmaktır" (Görüşmeci, I2). Mevsimine göre her tür yazlık ve kışlık sebzelerin yanında sedir, ardıç, zeytin, erik, kiraz, vişne, Trabzon hurması, erguvan, gülibrişim, dut, karadut, incir, böğürtlen, elma, hanımeli, nar, hatmi, demir ağacı, defne, lavanta, biberiye, katırtırnağı gibi ağaç ve bitkiler de dikilmiştir (Şekil I, 2).

Roma Bostanı ile aktif olarak ilgilenen çekirdek grup üç kişidir. Çekirdek grubun temel işlevleri bostanın tasarım sürecini planlamak, etkinlikler organize etmek ve bostana bakmaktır. Bostan, kuruluşta olduğu gibi yine tamamen sivil inisiyatifle ve bostancıların kendi kaynaklarıyla işlemekte, bir kamu veya özel kurum veya kuruluştan destek almamaktadır. Bostanın uzun erimli olması hedeflenmekte, bostan mahallenin ve kentin ka- 


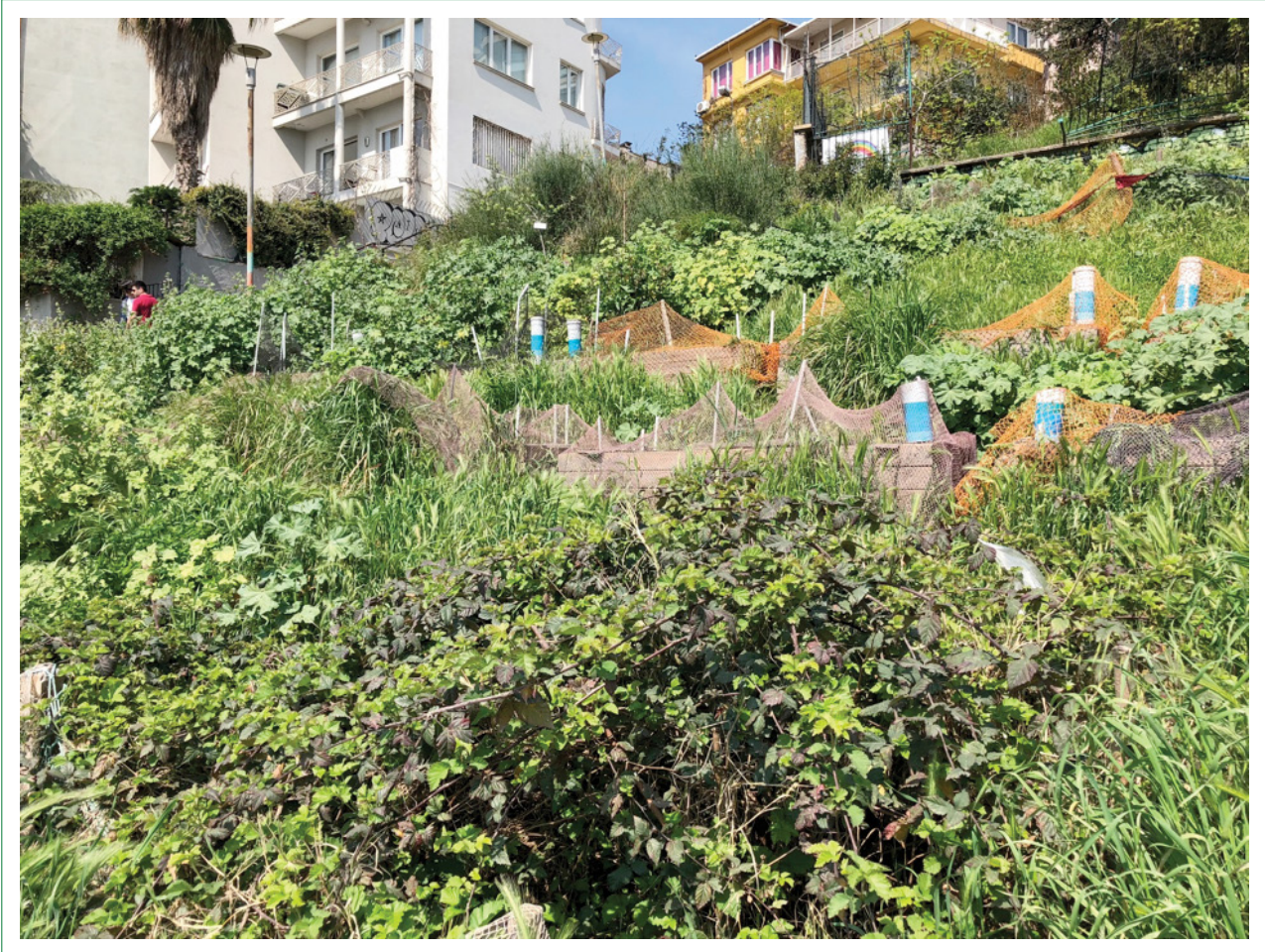

Şekil 2. Roma Bostanı, Cihangir. Nisan 2018.

lıcı bir parçası olarak ileriye dönük olarak da düşünülmektedir. Bostanda yoğun ekim işi olduğu zamanlarda bostanın internet ve sosyal medya sayfalarından tüm kente açık çağrı yapılmakta, böyle zamanlarda yardıma gelenlerin sayısı yüzü bulabilmektedir. Bostan yeniden hayata geçiş sürecinde de kamu otoritelerinden resmi bir izin almamıştır. Ancak kuruluş aşamasından farklı olarak Beyoğlu Belediyesi'nin içerisinde bostan arazisini de kapsayan "Sosyal Merkez Projesi” bostanın yanındaki otopark alanında başlayacak olduğundan bostancılar mahkemeden gelen bilirkişiye bostanı, motivasyonlarını ve yaptıklarını anlatan yazılı bir rapor sunmuşlar, bu anlamda belediye görevlileriyle yarı resmi bir karşılaşma yaşamışlardır.

Roma Bostanı aktörleri sadece içine konumlandığı Cihangir Mahallesi'ne değil bütün kente görünür olmaya ve tüm kentlilerin bostanı sahiplenmesine çok önem vermektedir. Bostancılar, bostanın internet sayfasını ve sosyal medya hesaplarını aktif olarak kullanmakta, düzenli güncellemeler ve paylaşımlar yapmakta, ve kentlilerin katılabileceği etkinlikler organize etmektedir. Bu bağlamda mahalledeki bir ilkokulun öğrencilerine bostanda permakültür kursları verilmiş, "Göçmen Dayanışma Mutfağı" ile bostan hasadı da kullanılarak yemek yapılmış, "Bombalara Karşı Sofralar" ile yine bostan hasadıyla yemek yapılarak paylaşılmıştır. Roma bostancılarının diğer sivil inisiyatif ve kent oluşumları ile aktif bir ilişki içerisinde olmak istedikleri de gözlemlenmiştir. Beyoğlu Kent Savunması, Yedikule Platformu, Kuzey Ormanları Savunması, Emek Platformu ve çeşitli permakültür oluşumları ile dayanışma ve destek ilişkile- ri kurulmuştur. Ayrıca mahalledeki bazı esnaf ve dükkanlar da bostana çeşitli şekillerde destek vermektedir. Örnek olarak su ile ilgili problem yaşandığında taşıma su desteği veren bir kafe olduğu gibi mahalledeki bir pizzacı da bostanda yapılan kompost için sigara küllerini biriktirip bostana vermektedir.

Bostanın mahalle ile olan somut ilişkisini ölçmek kolay değildir. Hatta bostan sadece mahalle için değil, bostanın yanından gelip geçenler, bostanı sadece merak edip bakmaya gelenler ve hatta bostan sayfasını sosyal medyadan takip edenler için de türlü anlamları olabilecek bir mekândır. Görüşmelerde bostancıların anlatımlarından bostancılar ve bostan çevresinde o anda bulunanlarla ilgili çoğu olumlu pek çok anlatım mevcuttur. Bostana fide hediye edenler, bostandan ürün toplayanlar, ekip biçmeye dair öneri verenler, hatta doğrudan toprakla çalışanlar sıklıkla karşılaşılan durumlardır. Bostanın sulama sorununa katkıda bulunan bitişik apartman ve bostanda ekip biçmeye yardım etmekle kalmayıp, bostana komşu olan evinin bahçesinde de ekim yapmaya başlayan din görevlisinin eşi sözü edilen ilişkilere bir örnek olarak gösterilebilir. Bunun yanında Roma bostancıları hem alternatif, hem de ana akım medyada çok defa yer almışlar, gazetelere, dergilere ve televizyon programlarına mülakat vermişlerdir. Bir bostancı bu çabayı kentlilere yaptıkları işi en iyi şekilde anlatmak ve bostanı tüm kentin sahiplenmesini sağlamak olarak açıklamıştır.

Bostanı ilk kuran Roma Bostancılarının temel motivasyonları, kentte yeşil alanların korunması ve sahiplenilmesi gerekliliği, 
bir araya gelinebilecek ve dayanışma içerisinde olunabilecek mekân ihtiyacı, toprakla ilişkilenmek, kentin yaşayanlar tarafından sahiplenilmesi ve birlikte üretmektir. Bostanın daha sonraki kullanıcılarında, birlikte üretmek, dayanışma ve kent mekânlarının sahiplenilmesine ek olarak ekolojik kaygılar, temiz ve sağlıklı gıda üretimi, üretim ve tüketim anlayışlarının değiştirilmesi gibi motivasyon ve kaygılar ön plana çıkmaktadır. Tüm görüşmeciler, ranta dayalı kentsel politikaları eleştirmekte, kentsel politikalar üretilirken yaşayanların istek, arzu ve taleplerinin, kenti yaşayanların eylemlerinin yok sayıldığını ifade etmektedirler. Bu bağlamda yabancılaşma, doğal çevreden kopuş, üretime dahil olamama, yalnızlık ve aidiyet sorunları bostancıların yaşadıkları kente ilişkin algılamalarının temelini oluşturmaktadır. Bostancılardan çoğu, bostancılık faaliyetlerini ve bostanı, egemen kent siyasetine direnmek ve muhalefet etmek olarak kavramsallaştırırken, bazıları bu terimlerle konuşmamakta, bostanı ve bostancılığı toprağa değmenin, gıda üretmenin ve bunu kolektif olarak kendi yaşadıkları yerde yapmanın tatmininin öneminden bahsedilmektedir. Bostancıların tümünde, kentsel mekânları metalaştırmadan, kolektif olarak dönüştürebilmek; bunu yaparken ekolojik prensipleri temel almak, doğrudan ve kolektif eylemle kenti talep etmek bostancılı̆ıı ve bostanın temel hedefi olarak ortaya çıkmaktadır.

\section{Kent Hakkı Bağlamında Katılımcı Bir Kamusal Mekân Talebi Olarak Roma Bostanı}

Birçok yazarın da dikkat çektiği üzere neoliberal süreçler kentlerde artan oranda eklemlenmekte; ayrıcalıklı tüketim mekânlarının çoğalması, güvenlikli siteler, büyük ölçekli kentsel dönüşüm projeleri, soylulaştırma ve kentsel girişimcilik yoluyla kent mekânları giderek parçalanmakta ve ayrışmaktadır (Peck \& Tickell, 2002; Smith, 2002; Swyngedouw, Moulaert \& Rodriguez, 2002). İstanbul'da özellikle son yıllarda kendini dayatan neoliberal kentsel yönetim kentsel mekânı metalaştırmakta, standartlaştırmakta ve kentsel katılımcılığı topyekun yok saymaktadır (Aksoy, 20ı4; Yalçıntan, Çalışkan, Çılgın \& Dündar, 2014). Bu bağlamda Roma Bostanı neoliberal kentsel politikalar karşısında "kent hakkı" çerçevesinde bir kamusal mekân talebi olarak analiz edilecektir. Kentsel mekânlardan sembolik ve fiziksel olarak dışarıda bırakıldı̌̆ını düşünen vatandaşlar, kolektif olarak bir araya gelmenin ve kendini ifade etmenin yollarının hem siyasal hem de mekânsal olarak ortadan kalktığı bir bağlamda, ortak emek, dayanışma ve paylaşma yoluyla bir sosyallik oluşturmakta ve mekânı temellük ederek somut bir talep ortaya koymaktadırlar. Roma Bostanı yoluyla ifadesini bulan talep, bireylerin kendini ifade edebilmesi, kendi inisiyatifleriyle kentsel çevrelerini bizzat şekillendirebilmesi, bir araya gelerek dayanışmacı bir topluluk yaratabilmesinin talebidir.

Son yıllarda akademik literatürde de sıklıkla yeniden tartışımaya başlanan "kent hakkı" kavramı Lefebvre'nin düşüncesine dayanmaktadır. Lefebvre, kapitalizmin kentte nasıl kendini ürettiğini ve yeniden ürettiğini araştırırken aynı zamanda kenti bu süreçlere direnmenin ve yeni bir mekânsallaşan hayat üretmenin de yeri olarak görmüştür (Lefebvre, 1991). Lefebvre'e göre "kent hakkı" "dönüşmüş ve yenilenmiş bir kent hayatı" hakkıdır (Lefebvre, 1996: I58). Attoh'un da dikkat çektiği üzere, akademik literatürde "kent hakkı" kavramından hareketle farklı kuramsallaştırmalar yapılmıştır (Attoh, 20II). Kimi yazarlar, bunun potansiyelleri üzerinde durarak farklı sorunları olan dezavantajlı grupların mücadelelerini ortak bir noktada buluşturabilecek bir kavram olarak "kent hakkı"nı önemserler (Mitchell \& Haynen, 2009). Bu anlamda kent hakkı; kimi zaman vatandaşılı hakkı, işgal hakkı, kamusal mekânı şekillendirme hakkı, kentsel politikalar karşısında otonomi hakkı, kimi zaman da konut, ulaşım, su gibi kaynaklarla ilişkili olarak sosyo-ekonomik bir hak olarak karşımıza çıkmakta, kentsel planlamaya katılım hakkından var olan mülkiyet kanunlarına karşı olan haklara uzanan bir yelpazede çeşitlenmiştir (Attoh, 20I I: 674-675).

Kent hakkının nasıl bir hak olduğu, kimler için kimler tarafından ve nasıl bir kentte talep edildiği meselesi de literatürde sıklıkla sorunsallaştırılmıştır. Tüm bu literatürde "kent hakkı" sanki verili olan düzende içerilebilmek için yoksun olunan belli hakları istemek ve/veya geri istemek, talep etmek bağlamında birçok hakka bölünmüş gibidir. Oysa, Lefebvre'in "kent hakkı" metni, düşüncesinin diğer boyutları ile beraber düşünüldüğünde önerdiği kavramın farklı grupların çeşitli kentsel hakları talep etmekten daha öte bir anlama sahip olduğu anlaşılacaktır. Zira Lefebvre "mekân" olgusunun temelinde politik olduğunu öne sürmüş ve mekânın üretiminin farklı bir toplum tahayyülü için elzem olduğunu iddia etmiştir (Lefebvre, 1991; Brenner \& Elden, 2009). Harvey, bu bağlamda "kent hakkı"nın bireysel bir hak olmadığını belirtir ve "kent hakkı"nın kaçınılmaz olarak alternatif bir toplum yaratma ve dönüştürme fikriyle ilişkili olduğunu söyler (Harvey, 2008: 23).

Harvey'e göre demokratik katılımcılığın alanı olacak yeni müşterekler yaratmak, yıkıcı ve yok edici neoliberalizmin mottosu haline gelen özelleştirme politikalarına karşı durmayı gerektirmekle beraber daha kapsayıcı kentler yaratmanın yolu "hakların yeniden düzenlenmesi değil", "farklı politik-ekonomik pratikler" kurgulamaktır (Harvey, 2003:94I). Bu yeni pratikler mekânsallaştığı ölçüde ve mekân dolayımıyla üretildiği ölçüde "kent hakkı" farklı hakların bir toplamından veya uzlaşımından öte bir anlama sahip olabilir. Marcuse (2009) ise "kent hakkı"nın "hukuki süreçle uygulanacak yasal bir iddia" olarak görülemeyeceğini belirtir (Marcuse, 2009: 192; Marcuse, 20I4:5). Ona göre kamusal alan, bilgi ve şeffaflık, merkeze erişim ve hizmetlere erişim hakkı birbirinden ayrılamaz bir bütünlüğün ve karmaşıklı̆ın parçalarıdır ve burada "kent hakkı"ndan kastedilen bu bütünlük hakkıdır ve bu hak var olan kente ilişkin değil, bir "gelecek kent"i tahayyül etmek, bu hakkı "gelecek kenti" için istemektir; böyle bir kent muhakkak eşitlik, adalet, demokrasi ve insan potansiyelinin sonuna ka- 
dar geliştirilmesi prensipleri üzerine inşa edilmek zorundadır (Marcuse, 2009: 193). Yani “kent hakkı” yasal ve yönetimsel bir hak değil, ahlaki bir iddiadır (Marcuse, 20I2; Mayer, 2009) ve bütünlüklü olarak talep edilmelidir (Marcuse, 20I2; 20I4). “Kent hakkı" "muhalif bir taleptir” (Mayer, 2009:367).

Purcell ise, "kent hakkı"nın iki temel hakkı içerdiğini ileri sürer; bunlar katılım hakkı ve temellük hakkıdır (Purcell, 2002:102; Purcell, 2008). Ona göre katılım hakkı temsili değil, doğrudandır. Purcell'in temellük hakkından kastı önceden verili bir alanı kullanabilme hakkı olmanın ötesinde temelde "kentsel mekânı onu yaşayanlarca kendi ihtiyaçları doğrultusunda üretebilme” hakkıdır (Purcell, 2008). Bu noktada, mekânın üretiminin temel dayanağı değişim değeri değil, kullanım değeridir. Neoliberal demokratik yönetimlerde büyük ölçüde çeşitli kurumlar tarafından filtre edilerek sağlanan dolaylı temsilin yerine Purcell, kentte yaşayanların doğrudan katılımını koyar. Başka bazı yazarlar da (Pugalis \& Giddings, 20I I) "kent hakkı”nı kente erişim, kentte var olabilme ve kente katılım hakkı olarak değerlendirirken, kentsel katılımın basitçe formel, bürokratik kanallarla sınırlı olmadığı, kentte aktif bir varoluşun ve kenti sürekli yeni ve yaratıcı biçimlerde kullanarak dönüştürmenin anlık değil, sürekli bir mücadele olarak kurgulanması gerektiğini belirtirler. Kent mekânlarını, kamusal mekânları ve kent mekânları ile ilgili alınan kararların, temsili yoldan veya çeşitli örgütlü yapılar içerisinden değil de doğrudan olması gerektiği, bu anlamda bostancıların pratiklerinde ve görüşmelerdeki anlatılarında açık seçiktir. Bir görüşmeci bunu şöyle ifade etmiştir:

"Yaşadığımız yeri bize sormadan yok edemezsiniz kardeşim. Hani bizi yok sayarak, biz hiç var olmamışız gibi bir takım kararlar alarak bizim hayatımız üzerinde bir yetki bir iktidar kuramazsınız, yaptı̆̆nız şeyi bize anlatmanız gerekir. Bizi de buna ikna etmeniz gerekir ve ikna olmuyorsak da eğer siz işte bir iktidar mekanizmasıysanız bunun adı devlet deyin, belediye deyin valilik deyin şu bu herhangi bir kurumda benim üzerime böyle bir oldu bitti ve emir komuta ile gelmeyin çünkü bizim için bir şey ifade etmiyor" (Görüşmeci, I3).

Çeşitli yazarların da belirttiği üzere, kentte yaşayanların kimisi zaten kentin sahibidir ve kentsel mekânlar iktidar sahiplerinin, yöneticilerin ve onların politikalarının bir sonucu olarak şekillenmektedir (Mayer, 2009; Marcuse, 2009). O zaman "kent hakkı" kentte yaşayan herkesten ziyade kentsel karar mekanizmalarına dahil olamayanların hakkı gibi gözükmektedir. Ancak farklı küresel ölçeklerde ve toplumsal düzenlemelerde kimin veya kimlerin bu mekanizmaların dışında kaldığı da başka bir sorudur. Marcuse (2009) bu sorunun cevabını "doğrudan baskı altında olanlar (dışlananlar) ve "yabancılaşmışlar" olarak verir; bu bağlamda "kent hakkı" herkes tarafından değil, Marcuse'un geliştirdiği şekliyle yoksun ve hoşnutsuzların, dışlanmış ve yabancılaşmışların talebidir (Marcuse, 2009: 190191). Bu hoşnutsuzluk duygusu iki görüşmeci tarafından şu şekilde ifade edilmektedir:
"Sokağa çıktığın anda aslında saldırı başlıyor, öyle hissediyorum çünkü şantiyeye döndü İstanbul, sürekli kepçeler ve beton arabalarıyla cebelleşiyoruz" (Görüşmeci, 2).

“Insanlar artık ürküyorlar sokağa çıkmaya, bir araya gelmekten çok korkuyorlar, bostan bunu aşabilecek bir yerde duruyormuş gibi geliyor bana çünkü seni suçlayabilecek hiçbir alan yok bostan içerisinde, meyve sebze ekmek için bir araya gelmiş insanlara ne diyebilirsin” (Görüşmeci, 3).

Roma bostancılarının bostanı bir gıda ormanına, bir yeşil alana dönüştürerek koruma ve savunma iradeleri ve kararlılıkları aynı zamanda kentsel mekânın tümünün ekolojik prensipler ve değerlerle yeniden düşünülmesi gerektiğine de işaret etmektedir. Bostancıların ortaklaşa emekleri, onların kentsel tasarım ve planlama bağlamında daha kolektif, dayanışmacı ve demokratik ilkeler gözetilmesi imasını da içerir. Purcell'in dikkat çektiği gibi "kentsel mekânın özel mülkiyet olarak kavranması; kapitalist üretim süreci tarafından bir meta olarak değer biçilmesi...tam da temellük hakkının karşı olduğu şeydir" (Purcell, 2002: 103). Bu bağlamda hem bostanı üreten pratiklerin, hem de bostanın kullanım değeri üzerinden kurgulanması kentsel mekânın özel mülkiyet olarak kavranmasına meydan okuduğu gibi neoliberal toplumsal ilişkilerin araçsallığını da sorunsallaştırmaktadır. Görüşmeciler dayanışmayı ve alternatif pratikleri ve şu şekilde anlatmıştır:

“işte insanlar, herkes bir şeyler getiriyordu. Bir şeyi yiyeceğiz, açız. Biri su getiriyor, biri çay getiriyor. Biri termosa bir şey koyuyor, biri pişiriyor... Herkes birbirine ikram ediyor işte. Mesela yani oraya götürdüğün malzemeleri hani kürek, o mesela yani müşterek, yani oradaki mülkiyet ilişkisini de kıran bir şey aslında" (Görüşmeci, I).

"Hepimiz başa sardık gibi olduğum bir dönemde orada yine o dayanışmayı görmek, bir arada iş yapmak insanlarla, o bilgiyi kimseyle hiçbir şey beklemeden karşılığında paylaşım yapmak... Hani daha önce hiç görmediğim insanların orada birbirine destek olduğunu görüyorsun" (Görüşmeci, 5).

Harvey de (2008) benzer şekilde “kent hakkı"nın var olan toplumsal ve mekânsal ilişkileri dönüştürerek kapitalizme meydan okuyabilecek bir potansiyeli olduğunu söylemiştir. Açıktır ki görüşme yapılan bostancıların pek çoğunun kapitalizm karşıtı kapsamlı bir politik gündemi yoktur ancak pratiklerinin verili kentsel üretim ve toplumsal ilişkiler karşısında alternatif oluşturabilecek potansiyeller taşıdığı söylenebilir. Birliktelik, dayanışma ve kolektiviteye yapılan vurgu, hiyerarşik olmayan lidersiz yatay ilişkilenme, gündelik hayatın ve kentsel mekânların metalaşmasına karşı duyulan açık tepki, tüketici değil üretici konumunda olmak gibi pratik ve değerlere yapılan vurgu bunun göstergesidir. Örneğin bir görüşmeci, bostanla olan ilişkisinde bostanda alınan somut üründen ziyade bostanın nasıl bir alternatif örgütlenme potansiyeli olabileceğini şu sözlerle dile getirmiştir: 
"Sonuçta ne düşünüyoruz, hayatta ne bekliyoruz, bilmiyorum ben mesela daha doğrudan demokrasiyi düşünüyorum ve doğrudan demokrasi nasıl bir şey olabilir; aşağıdan yukarı olabilir. Iş̧te bu mahallede biz beraber bir şey yaparsak, iki apartman biz konuşuruz sonra bizim bir mahalle böyle olur sonra bizim semt de olur. Hani, böyle bir şeyden çıkabiliyor, oturup kafeden çıkmıyor böyle şeyler. Bilmiyorum, bir başlangıç noktası bence yani böyle yerler" (Görüşmeci, 3).

Pek çok görüşmeci, bostanla ilgili motivasyonları ve bostanın kendileri için ne ifade ettiği sorulduğunda yaşam alanlarının kısıtlanmasına ilişkin cümleler kurmuşlardır. Bu bağlamda bir görüşmeci bostanı anlatırken, bostanı ve bostan pratiklerini yaşam alanına saldırı karşısında konumlandırmaktadır:

"Yaşam alanı bırakmıyor bize, işte bir tane hastanemiz vardı o da yok. Atıyorum, Beyoğlu'nda mesela deprem anında toplanılacak açık alan yok. Yani nerede toplanırsın işte Gezi Parkı'nda aslında gösterilen yer orası ama burayı da alacağım elinizden deniyor, şey, Yedikule Bostanlarını yerle bir ettiler, artık kalmadı bostan diye bir şey orada. Yani bütün yaşam alanlarımıza bir saldırı var ve biz de bunun karşısında duran insanları da görünce etrafinda ve bir şeye odaklanınca evet orada bir bostan var toprakla uğraşıyor herkes. Işsinden, zamanından ayırarak...şöyle söyleyeyim, herkes işinden çıkacak sonra bostanda toplanılır, bir iki saat çalışılır, ondan sonra gene gidilmez oturulur orada" (Görüşmeci, 5).

Görülmektedir ki, bostancıların talepleri sadece kentsel tasarım ve planlama kararlarına katılmak değil, rekabetten ziyade dayanışmaya, ranttan ziyade kullanım değerine, baskıdan ziyade kendini ifade etmeye dayanan daha demokratik, ekolojik, adil ve açık bir toplumu talep etme noktasında somutlaşmaktadır. Örneğin, birçok görüşmeci, bostanın temel özelliklerinin hiyerarşi olmaması, herkesin kendini ifade edebileceği bir yer olması ve bostanın işleyişinin karşılıklı öğrenme üzerinden eşitlikçi olarak kurulduğunu vurgulamışlardır. Bu anlamda bostan lidersiz, işlerin daha iyi bilenlerin ve/veya daha tecrübeli olanların "yol göstericiliğinde" yürüdüğü, katılımcıların kendi ilgi, yetenek, zaman ve çabaları ölçüsünde katkıda bulundukları bir mekân olarak ortaya çıkmaktadır.

“Belli şeylerle gidiyorsun. İşte bir pantolon, eldivenler, bir şey götürüyorsun zaten yanında, bakıyorsun mesela diyelim ki iş başlamış olabilir, birisi bir şey eliyor, yoruluyor. Eleği sen alıyorsun. Yapmayı bildiğin veya kolay öğrenebildiğin işler çünkü büyük bir "know how" gerektirmiyor. Toprak eleyeceksin. Biri diyor ki 'rüzgara doğru tutma, şöyle olur, yere yakın tut'. 'Haa, tamam'. (Görüşmeci, 9).

"Bostan gibi bir yerde emir aldığınız size emir veren size şunu yap bunu yap diyen birisi yok. Yaptığınız şey gönüllü ve gerçek. Yani katılmadığınız halde bir şey yapmak zorunda olmadığınız bir yer. Öyle olunca da çok sağlam bir direniş noktası yakalamıs oluyorsunuz var olan şeye karşı" (Görüşmeci, 8).

Bostancılar açısından, birlikte var olmak, üretmek, birbiriyle ilişkilenmek ve dayanışmak neredeyse bostanda ürün almaktan daha önemlidir. Görüşmeciler, Roma Bostanı'nda birbirleriyle ve farklı olanla ilişkilenmenin, yalnız olmadıklarını hissetmenin ve dostluğun mekânı olarak tarif etmişlerdir. Fırat ve Kuryel'in de belirttiği gibi “mekân aracılığıyla dayanışma ruhunu sürdürmek demek, ortak politik hayallere ve hedeflere sahip olmak, hakim öznellik ve görünürlük rejimlerine ait olmayı reddetmek" (Fırat \& Kuryel, 20I5:259) anlamına gelmektedir. Görüşmecilerin anlatısına bakıldığında bostanla kurdukları kişisel ilişki, bağlar ve aidiyetin kentte hissedilen baskı ve sıkıntının; dayanışma ve başkalarıyla yakınlıklar kurma ekseninde aşılma yolu olarak görülmektedir:

"Bostandan önce hepimiz kendi kabuğumuzda yaşayan insanlardık. Biraz daha sosyal olmayı keşfettik. Aynı idealle, ortak idealle bir şeye başladığınızdaki arkadaşlık ve dayanışma daha farklı bir şey” (Görüşmeci, 9).

Neoliberal kent politikalarınca kamusal alanın yok edilmesi, neyin meşru görülüp neyin görülmeyeceğinin sınırlarının net bir şekilde çizilmesi, kamusallığı ve kamusallık yoluyla üretilen dayanışmayı da hedef almaktadır. Bu bağlamda hem bostanda üretilen dayanışma, hem de diğer oluşumlarla kurulan ilişkiler en az yeşil alan üretmek kadar elzem görülmektedir. Bostan bu anlamda hem mekânı sahiplenerek, dönüştürerek savunmanın, hem de daha genel toplumsal, ekonomik, ekolojik endişelerin dile getirilip tartışıldığı; bunun da farklı oluşumlar, kolektifler ve ağlarla dayanışma ve karşılıklı öğrenme içerisinde yapıldı̆̆ı bir zemin olarak düşünülebilir.

“Dayanışmak zorundayız yani. DÜRTÜK bütün bostanlardan ürün toplamaya çalışıyor. Bütün ağlar şehirde daha güzel bir yaşamı hedefleyen herkese, yani gıdayla ilgilenen, doğayla ilgilenen, yeşille ilgilenen, şehir planlamasıla ilgilenen her şey bizim konumuz dahilinde zaten. Yani mesele şu; çok asimetrik ve askeri bir hiyerarşi var. Planlar yapılıyor, birileri bunu onaylıyor, bir şeyler oluyor ve biz burada yok sayılıyoruz. Esas tartışılması gereken şey bu” (Görüşmeci, I).

Neoliberal kent yönetimi kentsel mekânın diğer parçalarını da olduğu gibi neyin yeşil alan olarak kurgulanıp kurgulanamayacağını ve o yeşil alanda nelere izin verilip verilmeyeceğini belirleyerek mekânı kurgulamakta ve mekân üzerinde tahakküm kurmaktadır. Bostanlar bu anlamda da iktidarın mekânsal politikasına meydan okuyan ve onun koyduğu sınırları bulanıklaştıran yerlerdir (Mikazde, 20I5: 520). Ayrıca, kentte sebze üretiyor olmanın kendisi bizzat kır kent ayrımını bulanıklaştıran, üreten kır ile tüketen kent nosyonlarını sorunsallaştıran bir pratiktir. Bostan, yalnızca hakim neoliberal kent politikalarına değil, aynı zamanda kapitalizmin ürettiği yabancılaşmaya, gündelik hayatın standartlaşmasına, uzmanlaşmaya ve metalaşmaya da karşı; onun alternatiflerini üretebilecek bir mekân olarak da kurgulanmaktadır. Bu bağlamda Lefebvre'in "kendiliğindenlik" (spontaneity) ve “mücadele"(contestation) kavramlarını 
açımlamak da yerinde olacaktır. Lefebvre'e göre "mücadele" ekonomik taleplerle siyaseti birleştiren, entegre olmayı reddeden ve yabancılaşmaya karşı duran bir pratiktir (Lefebvre, 1969: 65-67). Siyasetin tanımlanmış kanallarının dışındadır ve siyasetin bir uzman etkinliği olmasına karşı çıkar. Mücadele "kendiliğinden" ortaya çıkar. "Kendiliğindenlik" olmadan ise ne bir olay ne de bir hareket olabilir (Lefebvre, 1969: 69-70). "Kendiliğindenliğin" yeri sokaklardır; sokaklar kurumlar tarafından ele geçirilmemiş toplumsallı̆̆ın yerleridir (ss. 70-7I). Bostan da bu anlamda, bir "kendiliğinden mücadele" alanıdır.

"O doğru şey bir araya geldiği zaman enerji ve motivasyonla işte bir takım işer yapmaya gönüllü insanlar ve onun çok da planlı ve ilerisini önünü çok net göremediğin bir halini, o spontaneliğin çok hoş bir şey olduğu o içindeyken öğrendiğin süreç. Çünkü bunlar bizim hayatımızda çok bürokrasi var ve her şeyi öğreniyoruz ya, her şeyin doğru tekniğini öğreniyoruz ve herkes ne iş yapıyorsa onunla ilgili eğitim alıyor, ben bu işteyim belki ama hala beni eğitime gönderip bu nasıl yapılmalı eğitimi veriyorlar. Her şeyimiz çok kalküle edilmiş bu hayatta, işte o onun çok tersi” (Görüşmeci, 2).

Bostanın mahalleyle kurduğu ilişki genelleşememiş olsa da bostancıların bostan çevresinde ve bostanda yaşadıkları pek çok "karşılaşma" onların tam da arzu ettiği bostanın kamusallığına ve açıklığına örnek oluşturacak cinstendir. Merrifield (2006: 7l) tam da "kent hakkı" kavramının öngördüğü kentin kullanım değerini önceleyen, canlı, yaşanan anlara ve "sihirli karşılaşmalara" olanak veren bir açık kamusallık önerdiğini söyler. Bir "karşılaşma mekânı" olarak bostan farklılıkların birbirinden öğrendiği, birbirine değdiği bir zemindir. Bir görüşmeci, belediyenin çöp toplayıcılarından bir tanesiyle yaşadığı karşılaşmayı şu şekilde anlatmaktadır:

"Ne yapıyorsunuz siz? dedi, Abi, bostan yapiyoruz. Ee, buradan çok çöp çıkıyor bilmem ne, bostan mı yapıyorsunuz? Evet, dedim. $E$, ben de anneme bir söyleyeyim dedi onun da dedi fasulyeleri vardi"(Görüşmeci, 4).

Bu karşılaşma anlarının yaratılmasının yanında bostanın mahalle ve kentliler nezdindeki algısı bostancılara göre bostanın meşruiyeti açısından da önemlidir. Görünürlük, özellikle medyada görünürlük bostanı ve bostancıların yaptığı işleri anlatmak ve gösterebilmenin yoludur. Özellikle yapılaşma tehdidi altında bir mekân olduğundan bostanın savunulması bütün kentin bostanı sahiplenmesinden geçmektedir. Kamu otoriteleriyle mücadele alanında da kentlilerin bostanı koruması, bostanın sadece mahalle için değil, tüm kent için anlamı olan bir mekâna dönüşmesi ile mümkün olabilecektir. Roma Bostanı tehdit altındaki bir kamusal alanı, son kalan yeşil alanı savunmayı bir meşruiyet zeminine yerleştirmeye uğraşır. Bir görüşmeci şöyle söylemiştir:

"Medyada özellikle çıktığı zaman, sonuçta biz hiçbir dernek değiliz, hiçbir şey değiliz. Bostanı belediyeyle karşı karşıya gel- diğimiz noktada hani en azından 'Bak burada yer aldık, şurada yer aldık. Burası böyle bir yerdi. Burası da kamu alanı. Burası da kamuya hizmet ediyor' diyebileceğimiz bir kaynak olsun istiyoruz aslında" (Görüşmeci, 13).

Bostancılar için ürün sembolik olmasına rağmen kolektif üretimin tek somut çıktısı olduğu için önemlidir. Bir anlamda orada "bir şey" yapıldığının kanıtıdır. Ürünün sembolik olmasının başka bir nedeni de bostandan az mahsül alınabilmesidir, bu da mahsülün daha geniş bir platformda veya mahalleyle paylaşılmasını zorlaştırmaktadır. Roma Bostancılarının atıl bir araziden bir bostan yaratma fikrini mahalleye yaratacağı sosyalekonomik faydadan ziyade kent politikalarına karşı duydukları yabancılaşma ve huzursuzluğun karşısında bir araya gelebilecekleri, dayanışma içinde olabilecekleri, kendilerini ait hissedebilecekleri, duygudaşlık kurabilecekleri ve ortak üretim yapabilecekleri bir mekân arayışı olarak okumak mümkündür.

"illk noktası bir direniş noktası olması, toprağa ayağının bastı̆̆ı, bu ülkenin senin ülken olduğunu ve onu iyi mutlu bir ülke olmasını istemenin sembolü gibi bir şey. Dostluğun, birlikte bir şey için uğraşmanın sembolü gibi. Hani birlikte bir sürü şey yapabileceğini gösteriyor olması, yalnız olmadığııın, tek başına evinde oturup işte hayaller kurup, vay ona buna çatıp buna küfredip buna kızıp yaşamadığın seninle aynı şeyi paylaşan aynı bakışı paylaşan bir sürü insanın olduğunu gösteriyor" (Görüşmeci, 6).

Schmid, "kent hakkı"nın, hayatın başka türlü olabileceği üzerine pratik bir deney olarak da düşünülebileceğini söyler (Schmid, 2012:43). Yani kent hakkı yalnızca yasal taleplerle ilgili değildir, bizzat alternatif hayat kurgularının denendiği, birbirine eklemlendiği, "başka bir toplum" kurgusunun hayata geçirildiği bir olasılıklar evrenidir. Bu araştırmanın konusunu oluşturan bostanlara bakıldığında bostanların kalıcılık ısrarının ve uzun vadeli projeksiyonlarının onları statükoya karşı somut bir politika üreticisi konumuna yerleştirdiği görülmektedir. Kolektif üreticilik ve paylaşım, yatay öz-örgütlenme ve doğrudan eylem gibi pratiklerle "başka bir dünyanın" talebi "şimdi ve burada" olanla sürekli harekete geçirildiği gibi bostancıların bostanı sürdürmedeki kararlı ısrarları da bu talebin geleceğe dönük sürekliliğini sağlamlaştııır.

"Kendi kendine organize oluyorsun, kendin yapıyorsun, başka bir şey düşünüyorsun, bir rüyan ya da düşün var, bunun ifadesi gibi bence.... Başka bir dünya, bu kadar çirkin olmayan yani, şehirden tut binalara, her şeye yani. Alternatiflerimiz bunlar diyebilmeliyiz. Ne istiyorsun; bunu istiyorum, nasıl istiyorsun; işte böyle istiyorum. Bunu yapıyoruz, şunu yapıyoruz. Ben kendimi böyle ifade edebilirim" (Görüşmeci, 3).

Bostancılar kullanılmayan atıl bir alanı ortaklaşa ekip biçerek yeşil bir alana dönüştürmüşler, bunu yaparken mahallenin ve kentlilerin zihinsel haritalarında Roma Bostanı'nı bir kamu- 
sal mekân olarak yerleştirip sahiplenilmesini amaçlamışlardır. Bostancıların her türlü medya aracılığıyla motivasyonlarını ve eylemlerini kentlilere anlatma çabası; tam da bu ilişkisellik yoluyla çevreleriyle kurdukları yapıcı iletişim; kamusal mekânın örgütlenmesinde alternatif olasılıkların varlığını göstermekle kalmayıp, aynı zamanda bostancıların eylem ve pratiklerinin somut sonuçlarıyla sürdürülebilir bir kent bahçesinin doğrudan ve tabandan katılımcılık yoluyla inşa edilebileceğinin de ispatı olmuştur. Katılımcılar dayanışmacı ve kolektif pratikleri yoluyla yalnızca bir yeşil alan yaratmakla kalmamışlar, mekânı dönüştürerek sahiplenmişler ve temellük etmişlerdir. Roma Bostanı yoluyla bostancılar kentsel mekânların üretilme, düzenlenme ve denetlenme biçimlerine meydan okumuşlardır. Roma Bostanı farklı katılımcıların bir araya gelerek, dayanışma, ortak üretim ve karşılıklı öğrenme yoluyla yalnızca sadece ekip biçtikleri değil, onun ötesinde dayanışmacı ve kolektif alternatif pratiklerin yeşerdiği ve sürdürüldüğü bir toplumsallık mekânı olmuştur. Bu anlamda sadece bostanın kendisi değil, aynı zamanda bostanı ortaya çıkaran pratikler ve toplumsallık "kent hakkı" talebinin somut olarak dile getirildiği mecra olmuştur. Bostancılık pratikleri, bostancıların kendilerini mekâna kazıyarak görünür oldukları ve mekânı arzu ettikleri biçimde işlev kazandırmalarının bir yolu olmakla kalmamış, aynı zamanda "kent hakkı" nın talep edildiği bir alan haline getirmiştir. Yalnızca bostandaki varlıkları değil, kolektivite, eşitlik ve açıklığa yaptıkları vurgu bu talebi bostanın mekânsal sınırlarının ötesine taşıyarak bir özgürlük ve demokrasi talebine dönüştürmüştür.

\section{Sonuç}

Bu makalenin amacı bir "kendin yap kentleşme” örneği olarak Roma Bostanı'nı “kent hakkı” kavramıyla ilişkilendirerek tartışmak ve kentsel katılımcılık bağlamında böyle pratiklerin olasılıklarını değerlendirmekti. Roma Bostanı neoliberal kent politikalarına karşıt olarak ortaya çıkmış, bostancıların sosyo-mekânsal örgütlenmeleri ve önerdikleri pratikler ile bostan dayanışmacı ve sürdürülebilir bir talebe dönüşmüştür. Bu çalışma göstermektedir ki, bir kentsel mekân talebi olarak Roma Bostanı neoliberal kent politikalarına karşı "kent hakkı" bağlamında değerlendirilebilir. Örgütlü kentsel mücadele veya alışılmış kentsel mücadele ve siyaset biçimlerinden farklı olsa da Roma Bostanı "kendin yap" pratikler yoluyla "kent hakkı" talebinin somut olarak dile getirildiği, bu anlamda da kentsel mücadelenin alternatif biçimlerini ve doğrudan katılımcılığı ortaya koyan çarpıcı bir örnektir. Roma Bostanı Cihangir Mahallesi'nde atıl bir alanı yeşil alana dönüştürmekle kalmamış, farklı toplulukların, birey ve grupların bir araya geldiği bir dayanışma mekânı olarak da inşa edilmiş, bostancıların nasıl bir kentte hangi değerlerle yaşamak istediğinin de kurgulandığı bir zemin olmuştur. Roma Bostanı'nın halen aktif bir bostan olması bu bostanın belirli bir kentsel mekâna yapılan ufak çaplı bir düzeltme veya iyileştirme olmanın çok ötesinde alterna- tif kentsel mücadele ve siyasetin kurgulanması açısından da önemli olduğunun göstergesidir.

Bu çalışmanın bir diğer araştırma sorusu "kendin yap" bostanların doğrudan katılımcı planlamanın bir örneği olarak değerlendirilip değerlendirilemeyeceği idi. Bu çalışmanın sahasını oluşturan Roma Bostanı da katılımcıların, öz örgütlenmeyle, kararların yatay düzlemde tartışılarak, birlikte karar vererek alındığı ve beraber uygulandığı bir örnek olarak karşımıza çıkmaktadır. Bu anlamda hem karar mekanizmalarına ve ortak eyleme doğrudan katılabilme, hem de mekânların nasıl şekillendirileceğine ilişkin bütün katmanlarda yer alma bostanın sahiplenilmesinde ve bostanın küçük ölçeğine rağmen kalıcı olmasında önemli bir rol oynamıştır. Bostancılar, yalnızca bir kentsel mekân kesitinin belirli bir şekilde planlamasında değil, orada üretilen alternatif bilgi ve pratikler ve farklı aktörlerle kurulan ilişkisellikler bağlamında planlamanın Lefebvre'ci anlayışla salt fiziki mekânın planlamasına yönelik bir uzman etkinliği olmadığını, alternatif bir dünyanın tahayyülünü ve tezahürünü içeren bir üretim pratiği olduğunu göstermişlerdir. Daha önce tartışıldığı üzere, katılımcı planlama anlayışı içerisinde değerlendirilen "taktiksel kentleşmenin" ve "kendin yap kentleşme" pratiklerinin kimi zaman neoliberalizmi ve neoliberal kent yönetimini destekler veya benimser nitelikte olduğu iddia edilmiştir. Oysa bu makale, İstanbul'un “kendin yap” Roma Bostanı'nın Brenner'in böyle müdahale biçimleri ve hegemonik kent politikaları arasında kurulabilecek ilişkilerden egemen kent politikalarını dönüştürebilecek potansiyele sahip olarak gördüğü "alt üst etme" ve "olumsallık” diye ifade ettiği biçimlere yakın olduğunu gözlemlemiştir. Türkiye bağlamında bostan, kentlerin büyüme odaklı, pazar yönelimli ve artan oranda otoriter yönetim mantığını alt üst eden doğrudan katılımcı, kullanım ve kullanıcı değerini öne çıkaran tabandan bir demokrasi örneğidir. Roma Bostanı alternatif pratiklerin ve imece ekonomilerinin gelişebileceği deneysel bir alan yaratması itibari ile Brenner'in söz ettiği biçimde "olumsaldır”. Taktiksel kentleşme belirli somut sorunlardan yola çıkarak bu sorunların çözümünü hiçbir siyasi sınıf, yapı ve uzman sınıfı kontrolünde olmayan kaynaklarla hayata geçirdiği ölçüde tabandan ve doğrudan katılımcıdır. Roma Bostanı arazisinin işgali ve oluşturulan bostan kentsel mekânların metalaşmasına, kamusal mekânın yok edilmesine ve kamusallığın ortadan kalkmasına yöneliktir. Roma Bostanı neoliberal politikaları sorgulamakta, bunun karşısına beraberce inşa edilecek ve yaratıcılığa, dayanışmaya açık, farklı katılımcılar ve oluşumlarla ilişki içerisinde dönüşen bir kent anlayışı, bir kent etiği koymaktadır. 


\section{KAYNAKLAR}

Adams, D. \& Hardman, M. (2014). Observing Guerillas in the Wild: Reinterpreting Practices of Urban Guerilla Gardening. Urban Studies, 5(6),1103-1119. doi: 10.1177/0042098013497410

Aksoy, A. (2014). İstanbul'un Neoliberalizmle İmtihanı. A. B. Candan ve C. Özbay (Ed.), Yeni İstanbul Çalışmaları: Sınırlar, Mücadeleler, Açılımlar içinde (s. 27-46). İstanbul: Metis.

Ateş, B. (2015). A Spatial Impromptu: Green Resistance By Guerilla Gardening. (Mastır Tezi). Ortadoğu Teknik Üniversitesi, Fen Bilimleri Enstitüsü, Ankara.

Attoh, A.K. (2011). What kind of right is the right to the city? Progress in Human Geography, 35(5), 669-685. doi: 10.1177/0309132510394706

Baker, E. L. (2004). Tending Cultural Landscapes and Food Citizenship in Toronto's Community Gardens. The Geographical Review, 94(3), $305-$ 352.

Bendt, P., Barthel, S. \& Colding, J. (2013). Civic greening and environmental learning in public-access community gardens in Berlin, Landscape and Urban Planning 109,18-30.

Bergdoll, B. (2015). Preface. P. Gadanho (Ed.), Uneven Growth Tactical Urbanisms for Expanding Megacities içinde (s. 10-13). New York, NY: The Museum of Modern Art.

Bishop, P. \& Williams, L. (2012). The Temporary City. London: Routledge.

Brenner, N. \& Elden, S. (2009). Introduction. State, Space, World: Lefebvre and the Survival of Capitalism. N. Brenner ve S. Elden (Ed.) State, Space, World Selected Essays içinde (s.1-48). Minneapolis:University of Minnesota Press

Brenner, N. (2015). Is "Tactical Urbanism" an Alternative to Neoliberal Urbanism? Post Notes on Modern and Contemporary Art Around the Globe. http://post.at.moma.org/content_items/587-is-tactical-urbanis Erişim tarihi: 06.05.2018

Certomà, C. (2011). Critical urban gardening as a post-environmentalist practice. Local Environment, 16(10), 977-987.

Crossan, J., Cumbers, A., McMaster, R. \& Shaw, D. (2016). Contesting Neoliberal Urbanism in Glasgow's Community Gardens: The Practice of DIY Citizenship. Antipode, 1-19. doi: 10.1111/anti.12220

Douglas, C.C.G. (2014). Do-It-Yourself Urban Design: The Social Practice of Informal "Improvement" Through Unauthorized Alteration. City \& Community, 13(1), 5-25. doi: 10.1111/cico.12029

Durusoy, E., \& Cihanger, D. (2016). Historic Landscape vs. Urban Commodity?: The Case of Yedikule Urban Gardens. İstanbul. Megaron, 11(1), 125-136. doi: 10.5505/MEGARON.2016.48343

Fabian, L. \& Samson, K. (2016). Claiming Participation - A Comparative Analysis of DIY Urbanism in Denmark. Journal of Urbanism: International Research on Placemaking and Urban Sustainability, 9(2), 166-184. doi: 10.1080/17549175.2015.1056207

Ferris, J., Norman, C. \& Sempik, J. (2001). People, Land and Sustainability: Community Gardens and the Social Dimension of Sustainable Development. Social Policy and Administration, 35(5): 559-568. http://illinoisonline,org/krassa/hdes598/Readings/People,\%20land,\%20and\%20 sustainability.pdf

Fırat, Ö. B. \& Kuryel, A. (2015). Yaratıcılık İş Başında: Karşı - Gösteriler ve Duygulanımsal Kolektiviteler. A. Kuryel ve B.Ö. Fırat (Ed.) Küresel Ayaklanmalar Çağında Direniş ve Estetik içinde (s. 243-267). İstanbul: İletișim.

Finn, D. (2014). DIY Urbanism: Implications for Cities. Journal of Urbanism:International Research on Placemaking and Urban Sustainability 7(4), 381-398. doi: 10.1080/17549175.2014.891149

Finn, D. (2014a). Introduction to the Special Issue on DIY urbanism. Journal of Urbanism: International Research on Placemaking and Urban Sustainability, 7(4), 331-332. doi: 10.1080/17549175.2014.959154

Gadanho, P. (2015). Mirroring Uneven Growth A Speculation on Tomorrow's Cities Today. Pedro Gadanho (Ed.), Uneven Growth Tactical Urbanisms for Expanding Megacities içinde (s. 14-25). New York, NY: The Museum of Modern Art.
Hardman, M. (2011). Understanding Guerrilla Gardening: An Exploration of Illegal Cultivation in the UK. Working Paper No. 1, Centre for Environment and Society Research, Birmingham.

Harvey, D. (2003). Right to the City. International Journal of Urban and Regional Research, 27(4), 939-941. doi: 10.1111/j.03091317.2003.00492.x

Harvey, D. (2008). The Right to the City. New Left Review, 53.

Holland, L. (2007). Diversity and Connection in Community Gardens: A Contribution to Local Sustainability. Local Environments, 9(3), 285-305. doi: $10.1080 / 1354983042000219388$

Hou, J. (2010). (Not) your everyday public space. J. Hou (Ed.), Insurgent Public Space Guerilla Urbanism and the Making of Contemporary Cities içinde (s. 1-17). London, UK: Routledge.

Iveson, K. (2013). Cities within the City: Do-It-Yourself Urbanism and the Right to the City. International Journal of Urban and Regional Research, 37(3), 941-956. doi:10.1111/1468-2427.12053

Kaldjian, J. P. (2004). Istanbul's Bostans: A Millenium of Market Gardens. The Geographical Review 94(3), 284-304.

Kaya, İ. A. \& Görgün, E. K. (2017). Kentsel mekân Üretiminde 'Kendin Yap' Hareketi. Planlama, 27(1), 57-74. doi: 10.14744/planlama.2017.74946

Lefebvre, H. (1969). The Explosion: Marxism and the French Upheavel. New York: Modern Reader Paperbacks.

Lefebvre, H. (1991). The Production of Space. Malden, Mass: Blackwell.

Lefebvre, H. (1996) Writings On Cities. E. Kofman \& E. Lebas (Ed.). Oxford: Blackwell.

Lydon, M. \& Garcia, A. (2015). Tactical Urbanism Short-term Action for Long-term Change. Washington, DC: Island Press.

Marcuse, P. (2009). From Critical Urban Theory to the Right to the City. City, 13(2-3), 185-197.doi: 10.1080/13604810902982177

Marcuse, P. (2012). Whose Right(s) to What City?. N. Brenner, P. Marcuse \& M. Mayer (Ed.), Cities For People Not For Profit Critical Urban Theory and the Right to the City içinde (s.24-41). London: Routledge.

Marcuse, P. (2014). Reading the Right to the City. City, 18(1), 4-9. doi: $10.1080 / 13604813.2014 .878110$

Marche, G. (2015). What Can Urban Gardening Really Do About Gentrification? A Case-Study of Three San Francisco Community Gardens. European Journal of American Studies 10(3), 1-8. http://ejas.revues. org/11316

Mares, T. M. \& Peña, D. G. (2010). Urban agriculture in the making of insurgent spaces in Los Angeles and Seattle. J. Hou (Ed.), Insurgent Public Space Guerilla Urbanism and the Making of Contemporary Cities içinde (s. 241-254). London, UK: Routledge.

Mayer, M. (2009). The 'Right to the City' in the Context of Shifting Mottos of Urban Social Movements. City, 13(2-3), 362-375. doi: $10.1080 / 13604810902982755$

Merrifield, A. (2006). Henri Lefevbre: A Critical Introduction. New York, London: Routledge.

Mikadze, V. (2015). Ephemeral Urban Landscapes of Guerrilla Gardeners: A Phenomenological Approach. Landscape Research, 40(5), 519-529. doi: 10.1080/01426397.2014.93961724

Mitchell, D. \& Heynen, N. (2009). The Geography of Sur- vival and the Right to the City: Speculations on Surveil- lance, Legal Innovation, and the Criminalization of Intervention. Urban Geography, 30: 611-630. doi: 10.2747/0272-3638.30.6.611

Peck, J. \& Tickell, A. (2002). Neoliberalizing Space. In N. Brenner \& N. Theodore (eds.), Urban Restructuring in North America and Western Europe, Blackwell Publishing, Malden, MA.

Pudup, M. B. (2008). It Takes A Garden: Cultivating Citizen- subjects in Organized Garden Projects. Geoforum, 39(3), 1228-1240. doi: 10.1016/j. geoforum.2007.06.012

Pugalis,L. \& Giddings, B. (2011). A Renewed Right to Urban Life: A Twenty- First Century Engagement with Lefebvre's Initial "Cry". Architectural Theory Review, 16(3), 278-295. doi: 10.1080/13264826.2011.623785

Purcell, M. (2002). Excavating Lefebvre: The Right to the City and its Urban 
Politics of the Inhabitant. GeoJournal, 58, 98-158. https://faculty.washington.edu/mpurcell/geojournal.pdf

Purcell, M. (2008). Recapturing Democracy Neoliberalization and the Struggle for Alternative Urban Futures. Routledge, London and New York.

Reynolds, R. (2008). On Guerilla Gardening: A Handbook For Gardening Without Boundaries. London: Bloomsbury.

Rosol, M. (2010). Public Participation in Post-Fordist Urban Green Space Governance: The Case of Community Gardens in Berlin. International Journal of Urban and Regional Research, 34(3), 548-63. doi:10.1111/ j.1468-2427.2010.00968.x

Rosol, M. (2012). Community Volunteering as Neoliberal Strategy? Green Space Production in Berlin. Antipode, 44(1), 239-257. doi: $10.1111 / \mathrm{j} .1467-8330.2011 .00861 . x$

Saldivar-Tanaka, L. \& Krasny, E. M. (2004). Culturing Community Development, Neighborhood Open Space, and Civic Agriculture: The Case of Latino Community Gardens in New York City. Agriculture and Human Values, 21, 399-412.

Sassen, S. (2015). Complex and Incomplete Spaces for Tactical Urbanism. P. Gadanho (Ed.), Uneven Growth Tactical Urbanisms for Expanding Megacities içinde (s. 40-47). New York, NY: The Museum of Modern Art.

Schmelzkopf, K. (2002). Incommensurability, Land Use, and The Right to Space: Community Gardens in New York City. Urban Geography, 23(4), 323-343. doi: $10.2747 / 0272-3638.23 .4 .323$

Schmid, C. (2012). Henri Lefebvre, The Right to the City, and the New Metropolitan Mainstream. N. Brenner, P. Marcuse \& M. Mayer (Ed.), Cities For People Not For Profit Critical Urban Theory and the Right to the City içinde (s. 42-62). London: Routledge.

Spataro, D. (2016). Against a de-politicized DIY urbanism: Food Not Bombs and the struggle over public space. Journal of Urbanism: International Research on Placemaking and Urban Sustainability, 9(2), 185-201. doi: 10.1080/17549175.2015.1056208

Swyngedouw, E., Moulaert, F., Rodriguez, A. (2002). Neoliberal Urbanization in Europe: Large-Scale Urban Development Projects and the New Urban Policy. In N. Brenner and N. Theodore (eds.), Urban Restructuring in North America and Western Europe. Blackwell Publishing, Malden, MA.

Talen, E. (2015). Do-it-Yourself Urbanism: A History. Journal of Planning History, 14(2), 135-148. doi: 10.1177/1538513214549325

Thompson, M. (2015). Between Boundaries: From Commoning and Guerrilla Gardening to Community Land Trust Development in Liverpool. Antipode, 47(4), 1021-1042. doi: 10.1111/anti.12154

Zardini, M. (2008). A new urban takeover. G. Borasi \& M. Zardini (Ed.), Actions: What you can do with the City içinde (s. 12-17). Montreal: SUN Architecture ve CCA.

Zeiger, M. (2011). The Interventionist's Toolkit, Part 1. The Design Observer. http://places.designobserver.com/entryprint.html?entry=25408 Erişim tarihi: 14 Mart 2011. 